\title{
The Use of IR Soldering Stations in the Process of Disassembling Circuits in BCA Packaging
}

\author{
Piotr Witkowski \\ Politechnika Opolska, Wydział Elektrotechniki, Automatyki i Informatyki, Instytut Elektroenergetyki i Energii Odnawialnej, \\ Katedra Inżynierii Biomedycznej, ul. Prószkowska 76 (bud. 2), 45-758 Opole
}

\begin{abstract}
This article presents the definition of a soldering profile and its division into individual phases. For the purpose of this article, an experiment was performed in which the influence of various factors such as - BGA package size, PCB size, the type of solder - on the temperature profile of a soldering process was investigated. The article is an overview and can serve as a guidebook for people who use soldering stations in their daily work to disassemble systems in BGA packages, or who plan to use such machines in their research.
\end{abstract}

Keywords: IFCBGA, IR soldering station, printed circuit board, reflow soldering, circuit disassembly

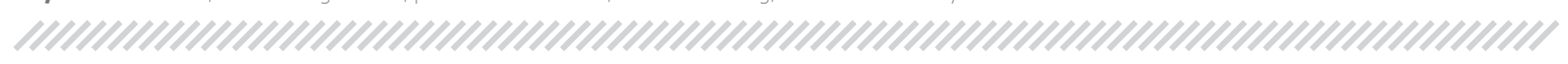

\section{Introduction}

Current technological development, the pursuit of miniaturization while increasing operational capabilities, have forced engineers to continue developing innovative packaging types for integrated circuit meeting the above requirements.

At present, circuits in BGA (Ball Grid Array) packages are very popular when it comes to solutions meeting certain criteria. The connection system are located underneath the package. Tin balls are used to connect the system to the laminate. The installation of this type of systems allows manufacturers to meet newer and more advanced criteria, but also poses some disadvantages, as specified below. A model system executed in a FCBGA (Flip Chip Ball Grid Array) package is shown in Figure 1 [1, 11-13, 16, 18].

In addition, the RoHS Directive (2002/95/EC), including its amendments, which have been in force in the European Union Member States since 2006, prohibit the manufacturers of electronic and electrical equipment from using lead-type materials, which had been in use as an admixture in adhesives for many years $[2,6,7,15,17]$.

Ongoing works have aimed at developing innovative alloy types which would be resistant to soldering defects whilst complying with EU regulations. At the same time, systems which generate less heat and consume less energy have been installed, which also affects the life of the solder metal found underneath the system.

Autor korespondujący:

Piotr Witkowski, piotr.witkowski@doktorant.po.edu.pl

Artykuł recenzowany

nadesłany 20.02.2020 r., przyjęty do druku 24.05.2020 r.

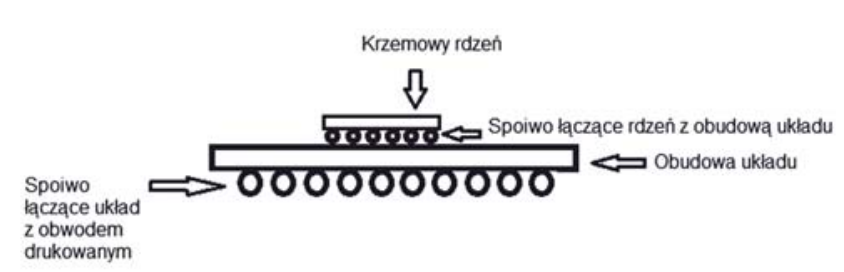

Fig. 1. A circuit in FCBGA packaging

Rys. 1. Układ w obudowie FCBGA

Lead-free soldering of any of the previously used alloys led to defects in production and service processes. To some extent, they have been limited in current solutions.

Such defects appear spontaneously, i.e. the occurrence of whiskers (threaded hair shapes up to $5 \mu \mathrm{m}$ in diameter and several millimeters long), short circuits caused by connecting several leads of the element with the solder metal as a result of the soldering process, and also due to human fault: incorrect selection of the soldering profile, which affects the quality of the connection, or a rapid increase in temperature, which, combined with moisture, leads to the formation of bubbles on the packaging (i.e. steam and other gases trapped in the packaging walls are the cause of delamination and cracking) [3-5, 14].

This article presents the definition of a soldering profile and its division into individual phases. For the purpose of the article, an experiment was conducted and consisted in soldering four BGA circuits with different packaging surfaces attached to different PCB surfaces. Apart from the differences in the size of the systems, the influence of the solder material type used on the course of the profile was observed (the first two systems were fixed with a lead-free solder, and the other two - with a tin-lead solder).

\section{Temperature profile}

A temperature (soldering) profile represents the relationship between the temperature rise and the duration of the reflow 
soldering process. The soldering profile is divided into four phases: preheat, soak, reflow, cooling. It is important to select an appropriate profile for the soldered elements in order to ensure their proper assembly in service processes [8-10, 19, 20].

For the purpose of the experiment, four standard phases with the temperature thresholds described below were used:

- Preheat - pre-heating of the PCB (Printed Circuit Board) to prevent deformations and moisture evaporation to prevent delamination. The phase takes place in the temperature range of $0-150{ }^{\circ} \mathrm{C}$. The flux must be applied when $140-150^{\circ} \mathrm{C}$ is reached.

- Soak - activation of the flux, cleaning of the solder and soldering pads is performed at $150-180{ }^{\circ} \mathrm{C}$ for lead-free solder and at $150-170{ }^{\circ} \mathrm{C}$ for tin-lead solder.

- Reflow - the purpose of proper soldering is to reach the solder reflow temperature. It is in this phase that proper metallurgical processes take place. $180-217^{\circ} \mathrm{C}$, depending on the lead-free solder alloy used, or $170-183{ }^{\circ} \mathrm{C}$ for tin-lead solder.

- Cooling - the purpose of the cooling phase is to dissipate the heat after the soldering process and to bring it to the initial temperature.

\section{Testing station}

The testing station (Fig. 2) was equipped with a Jovy Systems RE-7500 IR station. The selection of the testing station was based on its specifications - the station allows full control of the created soldering profile by controlling the lower and upper heater by means of power adjustment (bottom: 350 $\mathrm{W}, 450 \mathrm{~W}, 540 \mathrm{~W}$; top: $225 \mathrm{~W}$, $270 \mathrm{~W})$.

The following equipment were also used: a BGA reballing kit consisting of a special stand, screens for applying balls on the system, a vacuum gripper and a silicone stand for hot systems.

Temperature measurements were recorded using a computer connected to the soldering station, and then analysed.

In the experiment used a flux, genus: ROL0 - mild, low-active, colophony-based flux. Type: No Clean. Compliant with standards: ANSI J-STD-004 ROL0, Bellcore GR78 Core.

Four BGA packages with a $65 \mathrm{~nm}$ CMOS silicon technology dies flip-chipped in them were used for the test.

BGA packages of dimensions $30 \mathrm{~mm} \times 30 \mathrm{~mm}$ were assembled on the multilayer PCBs with organic protective od momentu rozpoczęcia procesu coatings type OSP of dimensions $210 \mathrm{~mm} \times 265 \mathrm{~mm}$. The test package on the underside of the enclosure have 899 ball joints. They are distributed evenly in $0.60 \mathrm{~mm}$ steps, distributed over the entire surface of the die. Balls of $0.50 \mathrm{~mm}$ diameter, made of alloys, were used: $\mathrm{Sn} 63 \mathrm{~Pb} 37$, hereinafter referred to as tin-lead solder, and $\mathrm{SnAg} 3 \mathrm{Cu} 05$ (SAC), hereinafter referred to as lead-free solder.

BGA packages of dimensions $40 \mathrm{~mm} \times 40 \mathrm{~mm}$ were mounted on the multilayer PCBs with organic protective coatings type OSP of dimensions $245 \mathrm{~mm} \times 270 \mathrm{~mm}$. The test package on the underside of the enclosure have 1042 ball joints. Distributed according to the shape of the manufacturer's proprietary matrix, spaced every $0.60 \mathrm{~mm}$, distributed over the entire surface of the system. Balls of $0.60 \mathrm{~mm}$ diameter, made of alloys, were used: $\mathrm{Sn} 63 \mathrm{~Pb} 37$, hereinafter referred to as tin lead solder, and $\mathrm{SnAg3Cu05}$ (SAC), hereinafter referred to as lead-free solder.

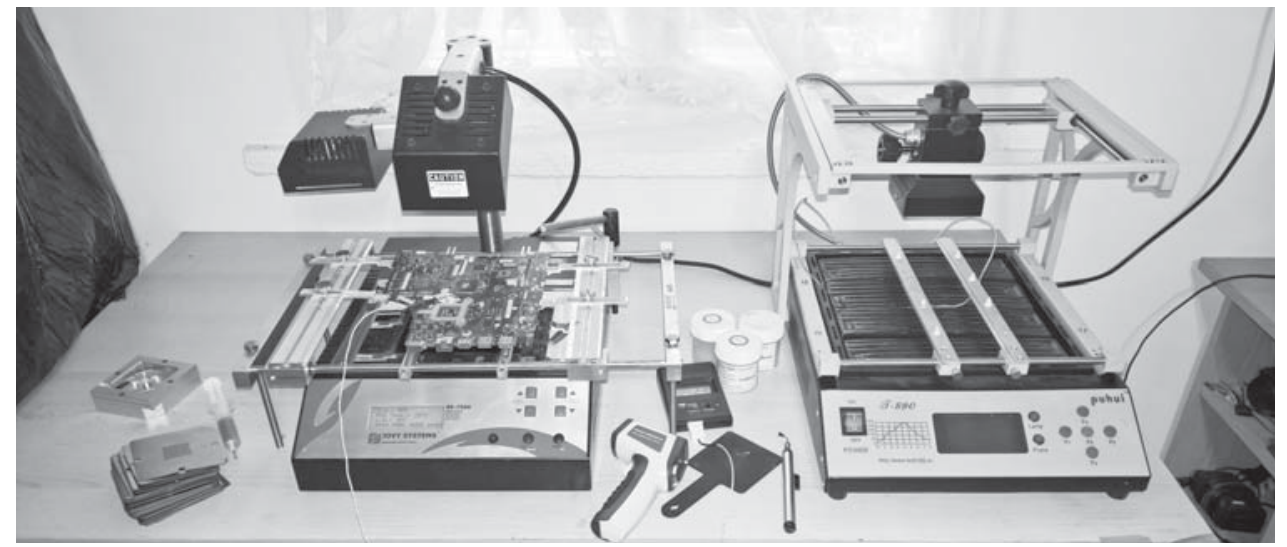

Fig. 2. Presentation of the testing station

Rys. 2. Prezentacja stanowiska testowego

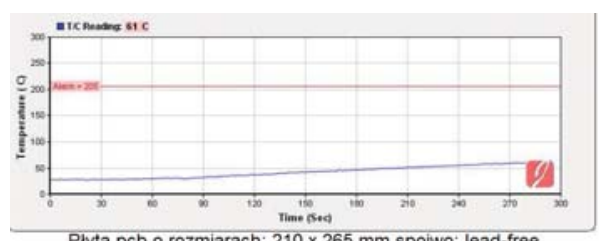

Plyta pcb o rozmiarach: $210 \times 265 \mathrm{~mm}$ spoiwo: lead-free

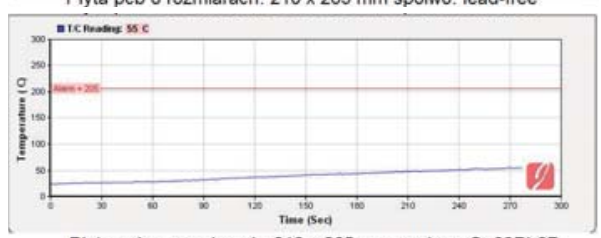

Plyta pcb o rozmiarach: $210 \times 265$ mm spoiwo: Sn63Pb37

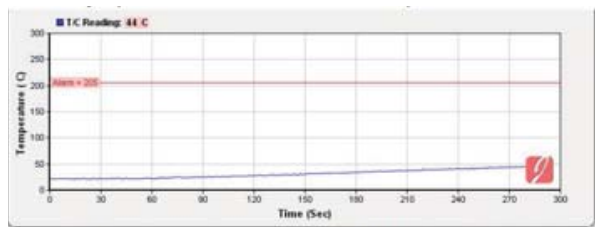

Plyta pcb o rozmiarach: $245 \times 270 \mathrm{~mm}$ spoiwo: Sn63Pb37

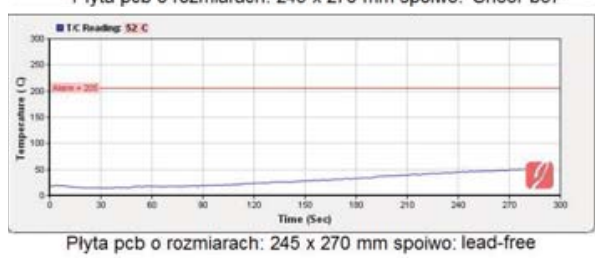

Fig. 3. Temperature increase in the first 5 minutes after the beginning of the soldering process Rys. 3. Wzrost temperatury w pierwszych 5 minutach
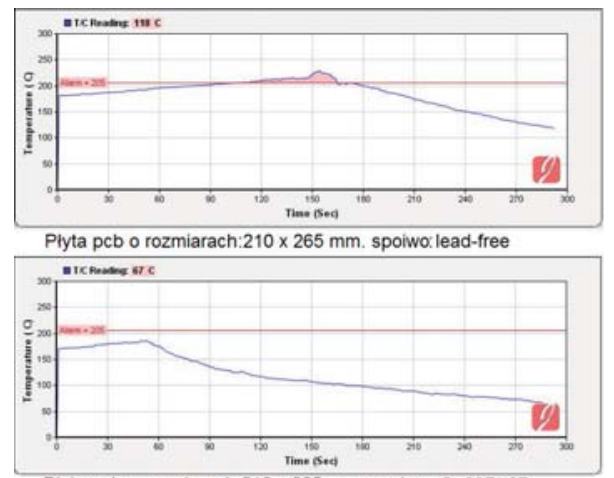

Pyta pcb o rozmiarach: $210 \times 265 \mathrm{~mm}$. spoiwo: Sn63Pb37

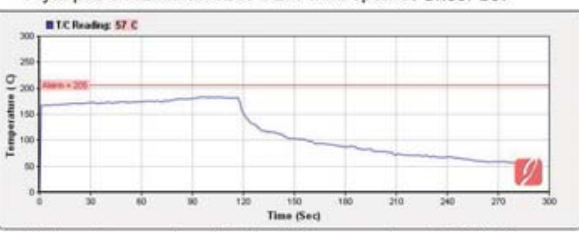

Plyta pcb o rozmiarach: $245 \times 270 \mathrm{~mm}$. spoiwo: Sn63Pb37

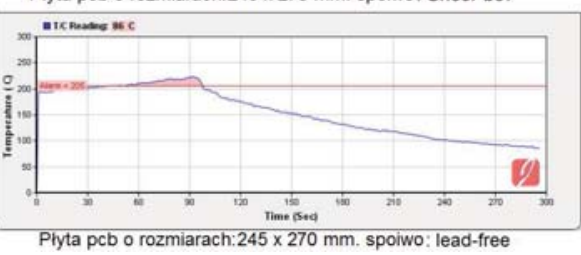

Fig. 4. Achievement of flow temperatures for each system and a presentation of the cooling phase Rys. 4. Osiągnięcie temperatury rozpływu oraz prezentacja fazy chłodzenia 


\begin{tabular}{|c|c|c|c|c|}
\hline & \multicolumn{2}{|c|}{ Lead-free technology } & \multicolumn{2}{c|}{ Lead-doped technology } \\
\hline & $\begin{array}{c}\text { Tested system no. 1: } \\
30 \mathrm{~mm} \times 30 \mathrm{~mm} \\
\text { PCB: } 210 \mathrm{~mm} \times 265 \mathrm{~mm}\end{array}$ & $\begin{array}{c}\text { Tested system no. 2: } \\
40 \mathrm{~mm} \times 40 \mathrm{~mm} \\
\text { PCB: } 245 \mathrm{~mm} \times 270 \mathrm{~mm}\end{array}$ & $\begin{array}{c}\text { Tested system no. 3: } \\
30 \mathrm{~mm} \times 30 \mathrm{~mm} \\
\text { PCB: } 210 \mathrm{~mm} \times 265 \mathrm{~mm}\end{array}$ & $\begin{array}{c}\text { Tested system no. } 4: \\
40 \mathrm{~mm} \times 40 \mathrm{~mm} \\
\text { PCB: } 245 \mathrm{~mm} \times 270 \mathrm{~mm}\end{array}$ \\
\hline Total disassembly time $[\mathrm{s}]$ & 1515 & 1615 & 1250 & 1360 \\
\hline Cooling time $[\mathrm{s}]$ & 300 & 410 & 390 & 420 \\
\hline $\begin{array}{l}\text { Average temperature rise } \\
\text { during disassembly }\left[{ }^{\circ} \mathrm{C} / \mathrm{s}\right]\end{array}$ & $\sim 0.12$ & $\sim 0.13$ & $\sim 0.14$ & $\sim 0.16$ \\
\hline \multirow{2}{*}{\begin{tabular}{l} 
Temperature drop $\left[{ }^{\circ} \mathrm{C} / \mathrm{s}\right]$ \\
\hline
\end{tabular}} & $\sim 0.46$ & $\sim 0.42$ & $\sim 0.35$ & $\sim 0.40$ \\
\hline
\end{tabular}

\section{The course of the experiment}

\subsection{Preparation of the tested BGA packages}

Before starting the experiment, two test packages were prepared by changing the solder metal. The old solder layer was removed by means of: a copper braid line, a soldering iron with the T-S3 tip and flux. When the old solder was removed from the packages, they were cleaned of flux residues using isopropanol. The packages were then dried in a PCB furnace, which heated the systems at $100{ }^{\circ} \mathrm{C}$ for 30 minutes. When the packages were dried, a system stand and stencil for direct heating were used. A tin-lead solder alloy was applied. Then, using the soldering station, the package was heated to $183{ }^{\circ} \mathrm{C}$, which resulted in the flow of the solder and its connection with the circuit fields of the package. Next, the packages were soldered using a soldering station.

To check the correctness of the assembly performed. First, basic measurements were taken with a multimeter and then heat sinks were mounted on the soldered packages, after which the plates were turned on and the soldered packages were tested by stress test durant 5 heures.

\subsection{Disassembly of the tested systems}

The course of the experiment is illustrated in Table 1.

\section{Conclusions}

This experiment has shown that an important factor to consider before starting the soldering process is the size of the surface of the board, to which the system is fixed. A significant difference between the time it takes to reach the individual temperature thresholds has become apparent. The heat dissipation through the PCB surface is an important factor for the reflow soldering process using the BGA repair soldering station.

Another important factor in the development of the profile by the technician should be to determine the type of solder used for assembling the system, which will result in the proper selection of the flow temperature.

Other factors which should be taken into account when creating the temperature profile for the soldering station are the division of the profile into individual phases - taking into account the processes taking place in each phase.

Following the above recommendations will certainly facilitate the development or selection of an adequate profile for the material obtained.

\section{References}

1. Anicai L., Petica A., Costovici S., Moise C., Brincoveanu O., Visan T., Electrodeposition of Sn-In Alloys Involving Deep Eutectic Solvents, "Coatings", 2019, DOI: 10.3390/coatings9120800.

2. Yang W., Du Z., Yu S., Li Y., Feng J., Wei X., Li Q., Zhan $\mathrm{Y}$. , The Effect of Rare Earths Additions on the Microstructure and the Corrosion Behavior of Sn-0.7Cu-0.075Al Solder Alloy, "Materials", 2019, DOI: 10.3390/ma12223731.

3. Koncz-Horváth D., Gergely G., Gácsi Z., Whisker-Like Formations in Sn-3.0Ag-Pb Alloys, Archives of Metallurgy and Materials, Vol. 62, No. 2B, 2017, 1027-1031,

DOI: 10.1515/amm-2017-0147.

4. Ren G., Collins M.N., Improved Reliability and Mechanical Performance of Ag Microalloyed Sn58Bi Solder Alloys, "Metals", 2019, DOI: 10.3390/met9040462.

5. Sidhu R.S., Aspandiar R., Vandervoort S., Amir D., Murtagian G., Impact of processing conditions and solder materials on surface mount assembly defects. "JOM", 63, 2011, 47-51, DOI: 10.1007/s11837-011-0174-3.

6. Wang K., Wang F., Huang Y., Qi K., Comprehensive Properties of a Novel Quaternary Sn-Bi-Sb-Ag Solder: Wettability, Interfacial Structure and Mechanical Properties, "Metals", 2019, DOI: 10.3390/met9070791.

7. Kobayashi T., Shohji I., Evaluation of Microstructures and Mechanical Properties of Sn-10Sb-Ni Lead-Free Solder Alloys with Small Amount of Ni Using Miniature Size Specimens, "Metals", 2019, DOI: 10.3390/met9121348.

8. Atieh A.M., Abedalaziz T.J., AlHazaa A., Weser M., Al-Kouz W.G., Sari M.S., Alhoweml I., Soldering of Passive Components Using Sn Nanoparticle Reinforced Solder Paste: Influence on Microstructure and Joint Strength, "Nanomaterials", 2019, DOI: 10.3390/nano9101478.

9. Huang Y.E., Hagen D., Dody G., Burnette T., Effect of solder reflow temperature profile on plastic package delamination, Proceedings of $23^{\text {rd }}$ IEEE/CPMT International Electronics Manufacturing Technology Symposium, 1998, 105-111, DOI: 10. 1109/IEMT.1998.731047.

10. Corbin S.F., High-temperature variable melting point $S n-S b$ lead-free solder pastes using transient liquid-phasepowder processing, "Journal of Electronic Materials", 2005, Vol. 34, 1016-1025, DOI: 10.1007/s11664-005-0089-2.

11. Kariya Y., Niimi T., Suga T., Otsuka M., Isothermal fatigue properties of $\mathrm{Sn}-\mathrm{Ag}$-Cu alloy evaluated by micro size spec- 
imen. "Materials Transactions", Vol. 46, 2005, 2309-2315, DOI: $10.2320 /$ matertrans.46.2309.

12. Intel Information Packaging Databook, Chapter 14, "Ball Grid Array (BGA) Packaging", www.intel.com/design/packtech/ch_14.pdf

13. Forsyth M., Seter M., Tan M.Y., Hinton B., Recent developments in corrosion inhibitors based on rare earth metal compounds. "Corrosion Engineering Science and Technology", Vol. 49, No. 2, 2014, 130-135, DOI: 10.1179/1743278214Y.0000000148.

14. Malaquias J.C., Steichen M., Thomassey M., Dale P.J., Electrodeposition of $\mathrm{Cu}$-In alloys from a choline chloride based deep eutectic solvent for photovoltaic applications, "Electrochimica Acta", Vol. 103, 2013, 15-22,

DOI: $10.1016 /$ j.electacta.2013.04.068.

15. Directive 2002/95/EC of The European Parliament and of the Council of 27 January 2003, On the restriction of the use of certain hazardous substances in electrical and electronic equipment.

16. Lai Z., Ye D., Microstructure and fracture behavior of non eutectic $S n-B i$ solder alloys. "Journal of Materials
Science: Materials in Electronics", Vol. 27, 2016, 3182-3192, DOI: $10.1007 / \mathrm{s} 10854-015-4143-4$.

17. Wang F., Li D., Zhang Z., Wu M., Yan C., Improvement on interfacial structure and properties of $\mathrm{Sn}-58 \mathrm{Bi} / \mathrm{Cu}$ joint using Sn-3.0Ag-0.5Cu solder as barrier, "Journal of Materials Science: Materials in Electronics”, Vol. 28, 19051-19060, DOI: $10.1007 / \mathrm{s} 10854-017-7859-5$.

18. Osório W.R., Spinelli J.E., Afonso C.R.M., Peixoto L.C., Garcia A., Microstructure, corrosion behavior and microhardness of a directionally solidified $\mathrm{Sn}-\mathrm{Cu}$ solder alloy. "Electrochimica Acta", Vol. 56, No. 24, 2011, 8891-8899, DOI: 10.1016/j.electacta.2011.07.114.

19. Drienovsky M., Trnkova L.R., Martinkovic M., Ozvold M., Cernickova I., Palcut M., Janovec J., Influence of cerium addition on microstructure and properties of $\mathrm{Sn}-\mathrm{Cu}-(\mathrm{Ag})$ solder alloys. "Materials Science and Engineering A", Vol. 623, 2015, 83-91, DOI: 10.1016/j.msea.2014.11.033.

20. Liu M., Yang W., Ma Y., Tang C., Tang H., Zhan Y., The electrochemical corrosion behavior of Pb-free Sn-8.5Zn-XCr solders in 3.5 wt.\% $\mathrm{NaCl}$ solution. "Materials Chemistry and Physics", Vol. 168, 2015, 27-34,

DOI: 10.1016/j.matchemphys.2015.10.003.

\title{
Zastosowanie stacji lutowniczych IR w procesie demontażu układów w obudowach BCA
}

\author{
Streszczenie: W artykule przedstawiono definicję profilu lutowniczego oraz jego podział na \\ poszczególne fazy. Na potrzeby artykułu przeprowadzono eksperyment, w którym zbadano wpływ \\ różnych czynników na proces demontażu/montażu, takich jak: wielkość układu BGA, wielkość \\ płytki drukowanej, rodzaj spoiwa, dobrany profil temperaturowy. Artykuł ma charakter poglądowy \\ i może służyć jako przewodnik dla osób, które w codziennej pracy wykorzystują stacje lutownicze \\ do demontażu układów w obudowach BGA lub planują wykorzystanie takich maszyn w swoich \\ badaniach.
}

Słowa kluczowe: FCBCA, stacja lutownicza, grzałka na podczerwień, płyta drukowana, demontaż układów

\section{mgr inż. Piotr Witkowski}

piotr.witkowski@doktorant.po.edu.pl ORCID: 0000-0002-2293-6462

AbsolwentWydziału Elektrotechniki, Automatyki i Informatyki, Politechniki Opolskiej na kierunku: Informatyka. Obecnie doktorant II roku studiów III stopnia na kierunku: Elektrotechnika Wydziału Elektrotechniki, Automatyki i Informatyki, Politechniki Opolskiej. Zainteresowania naukowe: przetwarzanie sygnałów, informatyka śledcza, obserwacja zjawisk zachodzących podczas procesów związanych z serwisowaniem elektroniki użytkowej.

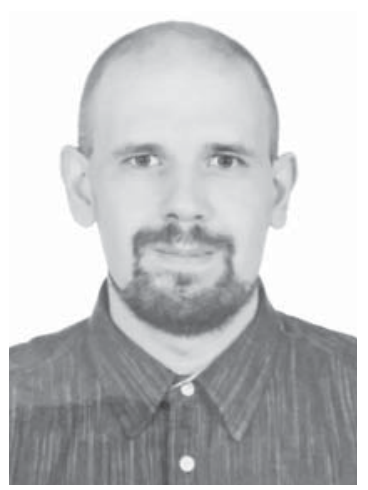

